\title{
Chemical Control of Nematodes and Insects in Tomato ${ }^{1}$
}

\author{
Nelia Acosta, Carlos Cruz and Edwin Abreu ${ }^{2}$
}

\begin{abstract}
The effectiveness of four nematicide-insecticides and three insecticides for the control of the reniform nematode (Rotylenchulus reniformis), vegetable leafminer (Lyriomyza sativae), and white grubs (Phyllophaga spp.) on tomatoes (Lycopersicon esculentum), was determined in three field experiments established in 1980 and 1981 at Isabela, Puerto Rico. In the first test permethrin, oxamyl and metamidophos effectively controlled leafminer. Acephate provided moderate control, whereas carbofuran and aldicarb were ineffective. All nematicide-insecticides were effective in the control of $\boldsymbol{R}$. reniformis in the soil. In the second test, lowest populations of white grubs were collected from plots treated with carbofuran and aldicarb, followed by those treated with oxamyl. In the third test there was a significant decrease of leaf-miner population in carbofuran- and permethrin-treated plots. A reduction of leafminer infestation was also obtained with aldicarb, pydrin and methamidophos. Significant yield increases were obtained from plots treated with both doses of acephate, permethrin, metamidophos and pydrin. Even though a nematode control over $60 \%$ was obtained in all treatments, yields from plots treated with nematicides were similar to that from the control, suggesting that yield increases cannot be attributed to insect control or nematode control only, but to the effect of these pesticides on unknown factors in the plant. No phytotoxicity was observed with any of the pesticides in any of the tests.
\end{abstract}

\section{INTRODUCTION}

Nematodes are a serious problem of vegetables in Puerto Rico; tomatoes are among those most affected. Even though this crop remains for a short time in the field, experimental data have demonstrated that the most common nematodes, Rotylenchulus reniformis, Meloidogyne spp., Helicotylenchus, spp., Tylenchorhynchus spp., Trichodorus spp., and others (8) are indeed pathogenic to these vegetables, causing yield losses (6, $7,8,10)$.

Various methods such as biological control (1), resistance (5), cultural practices (4), and chemical control $(2,6,7,8,9,10)$ have proven effective against nematodes in tomato roots.

The leafminer, Liriomyza sativae, is one of the most common insect pests of tomato. Heavy infestations early in the season may destroy the planting, whereas late infestations do not affect the yields $(11,12)$. White grubs (Phyllophaga spp.) are not common pests of tomato. However, if tomato is planted in fields near sugarcane or in fields previously planted to sugarcane, the probability of white grub damage is high.

The present studies were designed to determine the effectiveness of

${ }^{1}$ Manuscript submitted to Editorial Board February 7, 1983.

${ }^{2}$ Associate Nematologist, Entomologist and Research Assistant, Crop Protection Department, College of Agricultural Sciences, respectively. 
nematicide-insecticides on the control of nematodes, leafminers and white grubs; and to compare their efficacy with that of various insecticides.

\section{MATERIALS AND METHODS}

Field experiments were established at Isabela in 1980-1981 on a Coto clay ( $\mathrm{pH} 7.0$ and $2 \%$ organic matter) to determine the effectiveness of various nematicide-insecticides and insecticides against the primary nematode pest, $R$. reniformis, leafminer $L$. sativae, and white grubs ( $P h y l$ lophaga spp.) in tomato. Two doses (2.24 and $4.48 \mathrm{~kg}$ ai/ha) of nematicideinsecticides aldicarb $10 \mathrm{G}$, cabofuran $10 \mathrm{G}$, and ethoprop $10 \mathrm{G}$ were applied to the soil at planting. Experimental plots for the first test were established in January 1980, and consisted of three rows, each $30 \mathrm{~cm}$ wide and $600 \mathrm{~cm}$ long. Row spacing and plant spacing were $30 \mathrm{~cm}$ and $12 \mathrm{~cm}$, respectively. Granular nematicides applied from application jars by hand to $30 \mathrm{~cm}$-wide bands were incorporated $5-8 \mathrm{~cm}$ deep with a hoe, just prior to transplanting of 5 week-old seedlings of tomato cultivar Floradel. At planting Dacthal was applied for weed control.

Plants were air irrigated immediately after transplanting and as needed throughout the season. Plots treated with the lowest and highest doses of carbofuran received 3.36 and $6.72 \mathrm{~kg} / \mathrm{ha}$ (a.i.), respectively 4 weeks after the first application. Oxamyl L at 0.56 and $1.12 \mathrm{~kg} / \mathrm{ha}$ (a.i.) and two doses of the insecticides permethrin $2 \mathrm{E}(0.45$ and $0.89 \mathrm{~kg} / \mathrm{ha}$ a.i.), methamidophos $4 \mathrm{E}(0.56$ and $1.12 \mathrm{~kg} / \mathrm{ha}$ a.i. $)$, and acephate $75 \mathrm{~S}(0.74$ and $1.48 \mathrm{~kg} / \mathrm{ha}$ a.i.) were applied to the foliage with a 5 -gal knapsack sprayer at $40 \mathrm{lb} / \mathrm{in}^{2}$, one fan nozzle per row, every week throughout the season ( 5 weeks), starting in February.

Each experiment consisted of 15 treatments each one replicated four times and arranged in a partially-balanced incomplete block design. Untreated plots served as controls.

Soil samples for nematode analysis $\left(250 \mathrm{~cm}^{3}\right.$ per plot) were taken 15 $\mathrm{cm}$ deep before nematicide or insecticide application and 5 weeks after application. Nematodes were extracted from the soil with the modification of the Christie and Perry method (3).

Plants were attacked by mole crickets, for which two chlordane applications were given. Their control was difficult and the plots were abandoned. Nevertheless, on March 6, leafminer infestation was recorded by visual inspection on plants per plot. An index of 1 to 5 (1-least infested and 5-the most infested) was used.

The experiment was repeated April 1980 in an area previously planted to sugarcane. Treatments, methodology and plot size were as in the first test. Benomyl (Benlate) and Phenaminosulfos (Dexon) were applied in May and June to control diseases. Foliar treatments were performed 
weekly for 5 weeks. On July 9, methamidophos $4 \mathrm{E}$ at $1.12 \mathrm{~kg} / \mathrm{ha}$ was repeated to complete six applications.

Forty-five days after planting, data on yield per plot, number of nematodes and white grubs were recorded. White grub populations were estimated by counting all the larvae found in four holes $\left(0.30 \mathrm{~m}^{3}\right)$ per plot at planting and 4 months after planting.

Cultural pratices, control of weeds, fertilizer (10-10-8 applied at a rate of $1120 \mathrm{~kg} / \mathrm{ha}$ ) and application were those recommended by this Station. Results were statistically analyzed and differences between means evaluated for significance according to Duncan's multiple range test.

TABLE 1.-Effects of nematicides and insecticides applied at planting to the soil and post planting to the foliage for the control of leafminer in tomato Floradel, March, 1980, Isabela, Puerto Rico

\begin{tabular}{lcc}
\hline \multicolumn{1}{c}{ Treatment } & Rate & Leafminer index ${ }^{1}(1-5)$ \\
\hline & $k g / h a(a . i)$ & \\
Acephate 75S & 0.74 & 2.0 \\
Acephate 75S & 1.48 & 2.0 \\
Aldicarb 10G & 2.24 & 2.5 \\
Aldicarb 10G & 4.48 & 2.4 \\
Carbofuran 10G & 2.24 & 3.2 \\
Carbofuran 10G & 4.48 & 2.2 \\
Methamidophos 4E & 0.56 & 1.4 \\
Methamidophos 4E & 1.12 & 1.2 \\
Oxamyl L & 0.56 & 1.4 \\
Oxamyl L & 1.12 & 1.0 \\
Permethrin 2E & 0.45 & 1.0 \\
Permethrin 2E & 0.89 & 1.1 \\
Control & - & 3.0 \\
\hline
\end{tabular}

${ }^{1}$ Scale of 1 to $5,(1=$ plants without mines and $5=$ the most infested plants $)$.

A similar test was established February 1981 at Isabela with cultivar Walter. Treatments and methodology were similar to those used in previous tests. Pydrin $2.4 \mathrm{E}$ at rates of 0.18 and $0.36 \mathrm{~kg} / \mathrm{ha}$ was included instead of oxamyl L. Foliar treatments were initiated March 12, and continued weekly up to May 1 to complete seven applications. Applications of Chlorothalonil (Bravo 500) at $1.49 \mathrm{~kg} / \mathrm{ha}$, alternated with $\mathrm{Me}$ talaxil (Ridomil) at $0.28 \mathrm{~kg} / \mathrm{ha}$, were used for the control of fungal diseases. Leafminer infestation was recorded counting all the mined leaflets on a sample of 10 compound leaves selected from the middle of the plant from each plot. Fruitworm (Heliothis zea) damage was determined counting all the damaged fruits per plot.

\section{RESULTS AND DISCUSSION}

Table 1 shows the results from the first test. Lowest leafminer indices were obtained from permethrin, oxamyl and methamidophos. Acephate 
showed a moderate control, whereas aldicarb and carbofuran were ineffective. All nematicide-insecticides were effective in reducing initial nematode population levels (fig. 1).

In the second test, populations of white grubs increased up to 19.0 larvae per plot in the control, four months after planting. Nevertheless, lowest populations were found in carbofuran and aldicarb treated plots, followed by those treated with ethoprop (table 2). Higher yields were

TABLE 2.-Effects of nematicides and insecticides applied at planting to the soil and post planting to the foliage on yields of tomato Floradel, April 1980, Isabela, Puerto Rico

\begin{tabular}{lrrrr}
\hline \multirow{2}{*}{ Treatment } & \multirow{2}{*}{ Rate } & \multicolumn{2}{c}{ Yield/plot $^{1}$} & \multirow{2}{*}{$\begin{array}{c}\text { Number of white } \\
\text { grubs/plots }\end{array}$} \\
\cline { 2 - 3 } & $\mathrm{kg} /$ ha (a.i) & $\mathrm{kg}$ & \\
Acephate 75S & 0.74 & $5.23 \mathrm{AC}$ & $55 \mathrm{~B}$ & $-^{2}$ \\
Acephate 75S & 1.48 & $3.84 \mathrm{C}$ & $51 \mathrm{~B}$ & - \\
Aldicarb 10G & 1.24 & $7.82 \mathrm{ABC}$ & $83 \mathrm{AB}$ & $10 \mathrm{~A}$ \\
Aldicarb 10G & 4.48 & $5.96 \mathrm{ABC}$ & $71 \mathrm{AB}$ & $10 \mathrm{~A}$ \\
Carbofuran 10G & $2.4+3.36$ & $8.53 \mathrm{ABC}$ & $86 \mathrm{AB}$ & $9 \mathrm{~A}$ \\
Carbofuran 10G & $4.48+6.72$ & $8.64 \mathrm{ABC}$ & $100 \mathrm{AB}$ & $11 \mathrm{~A}$ \\
Ethoprop 10G & 2.24 & $7.25 \mathrm{ABC}$ & $87 \mathrm{AB}$ & $14 \mathrm{~A}$ \\
Ethoprop 10G & 4.48 & $9.42 \mathrm{AB}$ & $113 \mathrm{~A}$ & $11 \mathrm{~A}$ \\
Methamidophos 4E & 0.56 & $8.88 \mathrm{ABC}$ & $108 \mathrm{~A}$ & - \\
Methamidophos 4E & 1.12 & $10.42 \mathrm{~B}$ & $94 \mathrm{AB}$ & - \\
Oxamyl L & 0.56 & $7.36 \mathrm{ABC}$ & $82 \mathrm{AB}$ & $16 \mathrm{~A}$ \\
Oxamyl L & 1.12 & $7.35 \mathrm{ABC}$ & $81 \mathrm{AB}$ & $14 \mathrm{~A}$ \\
Permethrin 2E & 0.45 & $4.55 \mathrm{AC}$ & $69 \mathrm{AB}$ & - \\
Permethrin 2E & 0.89 & $8.06 \mathrm{ABC}$ & $102 \mathrm{AB}$ & - \\
Control & - & $5.27 \mathrm{C}$ & $73 \mathrm{AB}$ & $19 \mathrm{~A}$ \\
\hline
\end{tabular}

${ }^{1}$ Commercial fruits; values in the same column followed by the same letter, do not differ statistically $(\mathrm{P}=0.05)$, according to Duncan's multiple range test.

${ }^{2}$ Denotes (-) absence of data on control of white grubs.

obtained with both doses of methamidophos and $4.48 \mathrm{~kg} / \mathrm{ha}$ of ethoprop. Numbers of commercial fruits were higher in plots treated with ethoprop $(4.48 \mathrm{~kg} / \mathrm{ha})$. All nematicides were effective in reducing nematodes in the soil (fig. 1). No significant infestation of leafminer was detected.

Table 3 shows data from results in the third test. Even though leafminer infestation was low throughout the season, a significant decrease in populations (mined leaflets) was observed in plots treated with permethrin and carbofuran. A reduced infestation was also observed in plots treated with aldicarb, pydrin and methamidophos. No infestation of white grubs was detected. Significant higher yields were obtained from acephate, permethrin, methamidophos and pydrin treated plots. Even though all nematicides controlled nematodes effectively, this control was not reflected in production. 
Since the increase in yields could not be attributed directly to insect control or nematode control, we suggest that these effects could be attributed to unknown factors within the plant.

Oxamyl is as effective as permethrin and methamidophos against leafminer giving good nematode control. Different authors $(2,6,10)$ have also obtained good control of most nematode species in tomatoes using oxamyl. Yield increases in carbofuran- and aldicarb-treated plots from the second and third tests are apparently, the result of their effectiveness

TABLE 3.-Effects of nematicides and insecticides applied at planting to the soil and post planting to the foliage on yields of tomato Walter, February 1981, Isabela, Puerto Rico

\begin{tabular}{lrrrr}
\hline \multirow{2}{*}{ Treatment } & \multirow{2}{*}{ Rate } & \multicolumn{2}{c}{ Yield/plot $^{1}$} & \multirow{2}{*}{$\begin{array}{c}\text { Mined leaflet } \\
\text { per 10 leaves }\end{array}$} \\
\cline { 2 - 3 } & $\mathrm{kg} /$ ha $($ a.i. & $\mathrm{kg}$ & & \\
Acephate 75S & 0.74 & $20.7 \mathrm{~A}$ & $359 \mathrm{AC}$ & $16.3 \mathrm{~B}$ \\
Acephate 75S & 1.48 & $23.1 \mathrm{~A}$ & $467 \mathrm{~A}$ & $14.5 \mathrm{~B}$ \\
Aldicarb 10G & 2.24 & $12.7 \mathrm{~B}$ & $218 \mathrm{BC}$ & $8.3 \mathrm{~A}$ \\
Aldicarb 10G & 4.48 & $10.6 \mathrm{~B}$ & $207 \mathrm{BC}$ & $13.8 \mathrm{~B}$ \\
Carbofuran 10G & $2.24+3.36$ & $11.4 \mathrm{~B}$ & $204 \mathrm{~B}$ & $11.0 \mathrm{~B}$ \\
Carbofuran 10G & $4.48+6.72$ & $15.4 \mathrm{~B}$ & $314 \mathrm{BC}$ & $6.5 \mathrm{~A}$ \\
Ethoprop 10G & 2.24 & $13.7 \mathrm{~B}$ & $256 \mathrm{BC}$ & $22.0 \mathrm{~B}$ \\
Ethoprop 10G & 4.48 & $11.2 \mathrm{~B}$ & $209 \mathrm{BC}$ & $24.5 \mathrm{~B}$ \\
Methamidophos 4E & 0.56 & $16.8 \mathrm{~B}$ & $321 \mathrm{BC}$ & $10.5 \mathrm{~B}$ \\
Methamidophos 4E & 1.12 & $21.4 \mathrm{~A}$ & $413 \mathrm{~A}$ & $11.5 \mathrm{~B}$ \\
Permethrin 2E & 0.45 & $20.7 \mathrm{~A}$ & $375 \mathrm{~A}$ & $9.5 \mathrm{~A}$ \\
Permethrin 2E & 0.89 & $22.1 \mathrm{~A}$ & $370 \mathrm{~A}$ & $7.3 \mathrm{~A}$ \\
Pydrin 2.4E & 0.18 & $16.9 \mathrm{~B}$ & $340 \mathrm{AC}$ & $14.3 \mathrm{~B}$ \\
Pydrin 2.4E & 0.36 & $19.2 \mathrm{~A}$ & $357 \mathrm{BC}$ & $10.5 \mathrm{~B}$ \\
Control & - & $11.0 \mathrm{~B}$ & $243 \mathrm{C}$ & $18.5 \mathrm{~B}$ \\
\hline
\end{tabular}

${ }^{1}$ Commercial fruits; values in the same column followed by the same letters do not differ statistically $(P=0.5)$, according to Duncan's multiple range test.

as insecticides as well as nematicides. Overman (7) obtained over $100 \%$ yield increases of marketable tomato cultivar Manapal with preplant applications of carbofuran. No reference was made to its effects on leafminers or white grubs. Apparently the insecticides used in these tests have some nematicidal properties, but these properties have to be studied more in detail.

\section{RESUMEN}

En experimentos de campo establecidos en 1980 y 1981 en Isabela, Puerto Rico, se determinó la eficacia de cuatro nematicidas-insecticidas y tres insecticidas para el control del nematodo reniforme (Rotylenchulus reniformis), el minador de la hoja de hortalizas (Lyriomyza sativae) y gusanos blancos (Phyllophaga spp.) en tomate (Lycopersicon esculentum). 
Dos dosis de cada uno de los nematicidas-insecticidas, aldicarb 10G y carbofuran 10G, se aplicaron antes de sembrar. Oxamyl L y los insecticidas permethrin $2 \mathrm{E}$, methamidophos $4 \mathrm{E}$, y acephate $75 \mathrm{~S}$ se aplicaron al follaje cada semana por 5 a 7 semanas. La eficacia de los tratamientos se comparó con la de los testigos no tratados. Aunque en el primer experimento, la mayoria de las plantas fueron destruidas por changas (Scapteriscus vicinus), los datos sobre el control del minador de la hoja indicaron que permethrin, oxamyl y methamidophos fueron eficaces. Acephate los controló moderadamente, mientras que carbofuran y aldicarb fueron ineficaces. Todos los nematicidas-insecticidas controlaron eficazmente el $R$. reniformis en el suelo. En la segunda prueba, las poblaciones más bajas de gusanos blancos se colectaron en parcelas tratadas con carbofuran y aldicarb seguidas por las tratadas con oxamyl. En la tercera prueba, se obtuvo una baja significativa en la población del minador de la hoja, con tratamientos de aldicarb, pydrin y methamidophos. Se obtuvieron aumentos significativos en la producción en parcelas tratadas con ambas dosis de acephate, permethrin, methamidophos y pydrin. Aunque se obtuvo un control de nematodos de sobre $60 \%$ en todos los tratamientos, la producción de las parcelas tratadas con nematicidas-insecticidas fue similar a la de las no tratadas, lo que sugiere que los aumentos en producción no se pueden atribuir al control de insectos y nematodos únicamente, sino al efecto de los plaguicidas sobre reacciones desconocidas de la planta.

No se observó fitotoxicidad con ninguno de los plaguicidas en las tres pruebas.

\section{LITERATURE CITED}

1. Candanedo-Lay, E., J. Lara, P. Jatala, and F. González, 1982. Evaluación preliminar de comportamiento de Paecilomyces lilacinus como controlador biológico del nemátodo nodulador Meloidogyne incognita en tomate industrial, Nematrópica 12: (2). (Abstr.).

2. Colón-Ferrer, M. A., A. Ayala, y D. Cuebas, 1972. Resultados preliminares en el uso de nematicidas para el control de los nemátodos del tomate (Lycopersicon esculentum, Mill.) en suelos arenosos, Nematrópica 1:16 (Abstr.).

3. Christie, J. R. and V. G. Perry, 1951. Removing nematodes from soil, Proc. Helminthol. Soc. Wash. 18: 106-108.

4. Equiguren, R. y G. Robalino, 1981. Efecto de las enmiendas química y orgánica sobre la dinámica poblacional de Meloidogyne incognita en tomate, Nematrópica 11: 80 (Abstr.).

5. Fassuliotis, G. and D. P. Bhatt, 1981. The effect of cloning on the resistance of "patriot" tomato to Meloidogyne incognita race 1. Nematropica 11: 82. (Abstr.).

6. Fischnaler-Díaz, F. A., 1972. Determinación de la mejor frecuencia de aplicación del nematicida experimental D-1410 para el control de Meloidogyne spp. en tomate (Lycopersicon esculentum Mill.), Nematrópica 2: 17-8. (Abstr.).

7. Overman, A. J. and J. P. Jones, 1975. Carbofuran in a system approach to pest management in tomato, Nematropica 5: 26-27. (Abstr.).

8. Roman, J., X. Rivas, I. Reyes y G. Mangual, 1972. Estudios sobre el uso de nematicidas en las hortalizas, Nematrópica. 1: 23 (Abstr.). 
9. Singh, N. D., 1975. Effects of chemicals and plastic mulch on nematode populations and yield of tomato, Nematropica 5: 6-10.

10. _-, 1975. Influence of oxamyl application on Meloidogyne incognita and Rotylenchulus reniformis penetration into roots of tomato, lettuce, and pigeon peas, Nematropica 29 (Abstr.).

11. Smith, F. F., R. E. Webb and A. L. Bowell, 1974. Insecticidal control of a vegetable leafminer, J. Econ. Entomol. 67 (1): 108-10.

12. Wolfenbarger, D. A. and D. O. Wolfenbarger, 1966. Tomato yields and leafminer infestation and a sequential sampling plan for determining need for control treatments, J. Econ. Entomol. 59: 279-83. 